\title{
Management Efforts of Domestic Wastewater in Urban Based on Socio-Economic Variables
}

\author{
S. Sunarsih (Corresponding author) \\ Doctoral Program of Environmental Science, Diponegoro University \\ Jl. Imam Barjo, SH No. 5, Semarang 50241, Indonesia \\ Tel: 62-24-845-3635 E-mail : narsih_pdil@yahoo.com \\ P. Purwanto
}

Chemical Engineering Departement Faculty of Engineering Diponegoro University

Tembalang Campus, Semarang 50241, Indonesia

Tel.62-24-746-0058Ｅ-mail: purwanto@undip.ac.id

Wahyu Setia Budi

Faculty of Science and Mathematics, Diponegoro University

Tembalang Campus, Semarang 50241, Indonesia

Tel: 62-24-7468-0822Ｅ-mail: wahyu.sb@undip.ac.id

Received: May 10, 2013 Accepted: June 3, 2013

doi:10.5296/emsd.v2i2.3668 URL: http://dx.doi.org/10.5296/emsd.v2i2.3668

\begin{abstract}
This paper presents the analysis of data related to domestic wastewater characteristics from area situated in Yogyakarta city of Sewon Wastewater Treatment Plant (WWTP). BOD load, which has not been used, is $416 \mathrm{~kg} /$ day $(8.16 \%)$ in the ability of WWTP operational with the average rate of degradation for 1.85 day $^{-1}$ and the retention time for 4.27 day and also the ability to degrade average organic materials for $86,54 \%$. Simple regression models are presented for the prediction of basic wastewater characteristics, such as water consumption (1/person day), wastewater production $\left(\mathrm{m}^{3} /\right.$ day), Biochemical Oxygen Demand (BOD) load (l/person/day) and BOD concentration $(\mathrm{mg} / \mathrm{l})$. The models are based on simple socioeconomic variables, with special attention to easily obtainable variable of total family income
\end{abstract}


(number of minimum salaries earned per month). Most of the models are able to give an excellent prediction of the desired wastewater variables. Additionally, behavior of the main wastewater characteristics according to the day is analyzed used to variation data period 1.5 years. Based on the results obtained, it is suggested that the classical figures of BOD concentration of $413.69 \mathrm{mg} / \mathrm{l}$ and per capita BOD load 96.69 1/person/day do apply to typical population predominant in Yogyakarta city. The actual BOD data concentration are frequently lower than $300 \mathrm{mg} / \mathrm{l}$, while the BOD load is frequently lower than 96 1/person/day. Sewon IPAL is eficient enough in dealing with the process of wastewater treatment. The result obtained can be used for design purposes in the area studied, and possibly in areas of similar characteristics.

Keywords: domestic wastewater, socio-economic, BOD load, simple regression models

\section{Introduction}

Nowadays, settlements are more centered on housing areas. This causes new problems especially on the systems of sewer and garbage. The previous natural discharge, draining it to the rivers, had been considered successful. At first, it did not cause any problem since the amount of garbage was little. However, the increasing waste disposal results in the increasing environmental contamination. The centered settlements make the high accumulation of household waste in the sewer. It reduces the quality of water in rivers if the waste has not been processed properly first.To solve this problem, the waste needs to be processed. One of the processes is by using WWTP.

Quality problems in built environments of society settlements of most big cities in Indonesia become multi-dimension problems. The rapid developments of big cities are marked by the more increasing number of population in cities. It has impacts on the volume of solid and liquid waste produced. Therefore, the production of waste per unit area also increases (Soemarwoto, 1983). If there is no appropriate action to handle this problem, so it will cause a serious problem. The more dense the area, the more complex the contamination, especially dealing with household or domestic waste. Uncontrolled domestic waste has contaminated most rivers in Indonesia, especially Java (Hadi S. P. and Samekto Adjie, 2007).

Domestic or household waste consists of dirty water disposal of bathrooms, toilets, and kitchens. This dirt is the mixture of mineral and organic elements in various shapes, including big and small particles, solid, floated residues scraps and colloid and half colloidal (Martopo S, 1987).

Generally, biological treatment is used to reduce and lower the level of organic contamination in wastewater. It uses and utilizes microorganism liveliness (Mahida, 1993), for example by using activated sludge, tricling filter) and waste stabilization ponds.

Waste stabilization ponds are used to repair the quality of wastewater relied on natural processes using the existance of bacteria, algae and zooplankton to reduce organic pollutants in wastewater (Kayombo et al., 2002; Beran and Kargi, 2005; Puspita L., et al., 2005). 


\section{Macrothink}

Commonly used disposal system is draining the wastewater from toilets into septic tanks. Then, the runoff water from the septic tanks is absorbed on the ground or disposed to public canals. While the non toilet wastewater from bathrooms and kitchens is directly disposed to the public canals.

The aim of this research is as an means to control domestic wastewater contamination in cities which is commonly disposed through cities sewer networks and led into centered WWTP, that predicts organic waste load.

The importance in building the centered WWTP is to support the program of clean rivers (Prokasih), to prevent or reduce soil contamination, to save private treatment manufacture and to increase healthy environment improvement. Waste stabilization ponds are suitable to be applied on the developing countries (especially in tropical areas with warm climates), since the treatment of these ponds does not need high investment and treatment fees. They also do not need special operators (Mara D., et al., 1992; Mashauri and Kayombo et al, 2002; Beran and Kargi, 2005; Puspita L., et al, 2005).

\section{Research Methods}

The material used in this research is liquid waste from WWTP Sewon Bantul Yogyakarta. Daily discharge data is collected from wastewater quality control results of July 2010 December 2011.

The wastewater customer retribution data from the Infrastructure Settlement Office of Yogyakarta in 2011 is used to know the number of population connected with wastewater sewers and household income data of Province Minimum Wage data (UMP) from BPS Yogyakarta in 2010 - 2012.

By using simple regression analysis, the generation of waste water can be predicted. The loads of organic materials in IPAL unit can be determined from the total of concentration of $\mathrm{BOD}$, so that the eficiency of waste loads can be compared to the planningned design standard.

\section{Results and Discussion}

\subsection{Management Efforts of Domestic Wastewater}

To create a clean and healthy city of Yogyakarta, domestic wastewater treatment is regulated according to Perda No.6 Year 2009 and Perda No. 7 Year 2009 about retribution. The medium is managed by the Infrastructure Settlement Office of Yogyakarta in Settlement Area Wastewater Section. In 2010, based on the population census, Yogyakarta had 388,627 people. It is clasified into a medium city. The ideal water needs is 100 liter/person/day so that it needs $38,862,700$ liter/day for a medium city.

The level of BOD (Biochemical Oxygen Demand) becomes a determinant factor for the amount of organic waste produced per person/day. Each country has different variations. The biggest difference is based on the quantity and quality of wastewater body and food variety. Therefore, the population, connected with waste sewer systems, is firstly calculated to 
determine organic waste loads. The waste sewer systems consisting of households, offices, and hotels with the following calculations:

- Households (R1+R2+R3+R4), inhabited by 5 people evenly : 54,440 people

- $\quad$ Social $(\mathrm{S} 1+\mathrm{S} 2+\mathrm{S} 3+\mathrm{S} 4), 75$ people evenly

: $\quad 8,550$ people

- Comercial $(\mathrm{K} 1+\mathrm{K} 2+\mathrm{K} 3+\mathrm{K} 4), 50$ people evenly : $\quad 49,350$ people

- Hotel (PW+HM+H1-3+H4-5), 1 room 2 people evenly

The number of people linked by wastewater sewers

To predict organic waste load, simple regression analysis method is used by significant level $\alpha=10 \%$, the following equation is resulted:

$$
q=95.112+(5.309 E-5) N_{U M P}
$$

with $q$ : wastewater generation (1/person/day)

$N_{U M}$, minimum wage (UMP)

UMP Yogyakarta in the year of 2012 was Rp.892.660,- (Eight hundreds ninety two thousands six hundreds and sixty) per month. If it is converted into dollar (Rp.9.000,-) it becomes $\$ 3,306 /$ month, generation of wastewater from the equation (1) is 96.69 liter/person/day, while organic material concentration is $413.69 \mathrm{mg} / \mathrm{l}$, so that the total concentration of BOD in WWTP Sewon Yogyakarta is 4,963.9 kg/day and the average flow of wastewater is $10,697.53$ $\mathrm{m}^{3} /$ day. Based on the planning of wastewater capacity entry, that is $15,500 \mathrm{~m}^{3} /$ day, it can be determined that it has not exceeded the planning capacity. According to Mara (2004), clean water need standard for developing countries is 120 liter/person/day and every Indonesian generates 40 gr BOD per day. Then, wastewater generation assumption of $80 \%$ is 96 liter/person/day and wasteloads concentration is $416.67 \mathrm{mg} / \mathrm{liter}$ (ppm BOD), so that the total BOD loads is $4,799.6 \mathrm{~kg} /$ day and the planning standard is $5,103 \mathrm{~kg} /$ day, every person generates 46 gr BOD per day. Campos and von Sperling (1996) estimate the wastewater generation in Brazil using the following equation:

$$
q=58+8 N_{U M P}
$$

By using the equation (2) that is applied to Yogyakarta with $N_{U M P}$ is UMP that is converted to dollar (Rp.9000,-) with the rate of household income used was Yogyakarta Minimum Wage (UMP) in 2011 of Rp. 808.000,-/month equivalent with \$2,993, then wastewater generation of 81.94 liter/person/day, while the concentration loads of $\operatorname{BOD}\left(L_{i}\right)$ per person/day is calculated by using formula Mara (2004):

$$
L_{i}=247+\exp \left(5.9-0.26 N_{U M P}\right)
$$




\section{Macrothink}

Environmental Management and Sustainable Development

ISSN 2164-7682

2013, Vol. 2, No. 2

So, the BOD loads concentration per person/day is $414.66 \mathrm{mg} / \mathrm{liter}$ (ppm BOD) and the BOD loads concentration is multiplied by the number of people linked by sewer system for about $4,975.48 \mathrm{~kg} /$ day. The result of organic material loads analysis in detail is presented in Table 1 .

Table 1. The Analysis Result of Organic Matter Loads of Sewon WWTP

\begin{tabular}{llccc}
\hline No. & \multicolumn{1}{c}{ Wastewater } & $\begin{array}{c}\text { Developing } \\
\text { Countries } \\
\text { Mara (2004) }\end{array}$ & $\begin{array}{c}\text { Campos and von } \\
\text { Sperling (1996) }\end{array}$ & $\begin{array}{c}\text { Researchers } \\
(2013)\end{array}$ \\
\hline 1. $\quad \begin{array}{l}\text { Wastewater generation } \\
\text { (liter/person .day) }\end{array}$ & 96.00 & 81.94 & 96.69 \\
2. $\quad \begin{array}{l}\text { Wastewater } \\
\text { concentration (mg/l) }\end{array}$ & 416.67 & 414.66 & 413.69 \\
$\begin{array}{l}\text { Total of wastewater } \\
\text { loads concentration } \\
\text { (kg/day) }\end{array}$ & 4,995 & 4,975 & $4,799.6$ \\
\hline
\end{tabular}

Table 1 shows the similar level of concentration of wastewater of various researchers. Mara's concept of wastewater generation is slightly different with others (2013). There is a deviation of 0.69 liter/person/day (0.71\%), while Campos and von Sperling (1996) has 14.75 liter/ person/day (15.25\%). There is a similarity of the total of wastewater concentration. For Campos and von Sperling (1996) and Mara (2004), there is a slight deviation of $20 \mathrm{~kg} / \mathrm{day}$ $(0,4 \%)$. According to Campos and von Sperling (1996), debit or waste flow is determined by wastewater generation with the following equation:

$$
Q=10^{-3} k q(P d k)
$$

with $Q$ : wastewater flow $\left(\mathrm{m}^{3} /\right.$ day)

$k$ : konsanta $0,8-0,9$

$q$ : people's basic needs of water for a medium clasification (100 liter/person/day)

$P d k:$ the number of people linked by sewer system

Therefore, equation (4) of $10,799.10 \mathrm{~m}^{3} /$ day is used to determine wastewater discharge in WWTP Sewon. If it is compared with wastewater discharge of the average discharge measurement result of $10,697.53 \mathrm{~m}^{3} /$ day, it is generated a deviation of $101.57 \mathrm{~m}^{3} /$ day $(0.94 \%)$. Thus, wastewater discharge is almost appropriate with the current condition. Figure 1 shows the condition of daily wastewater discharge in Sewon WWTP in January 2011 - December 2011. 


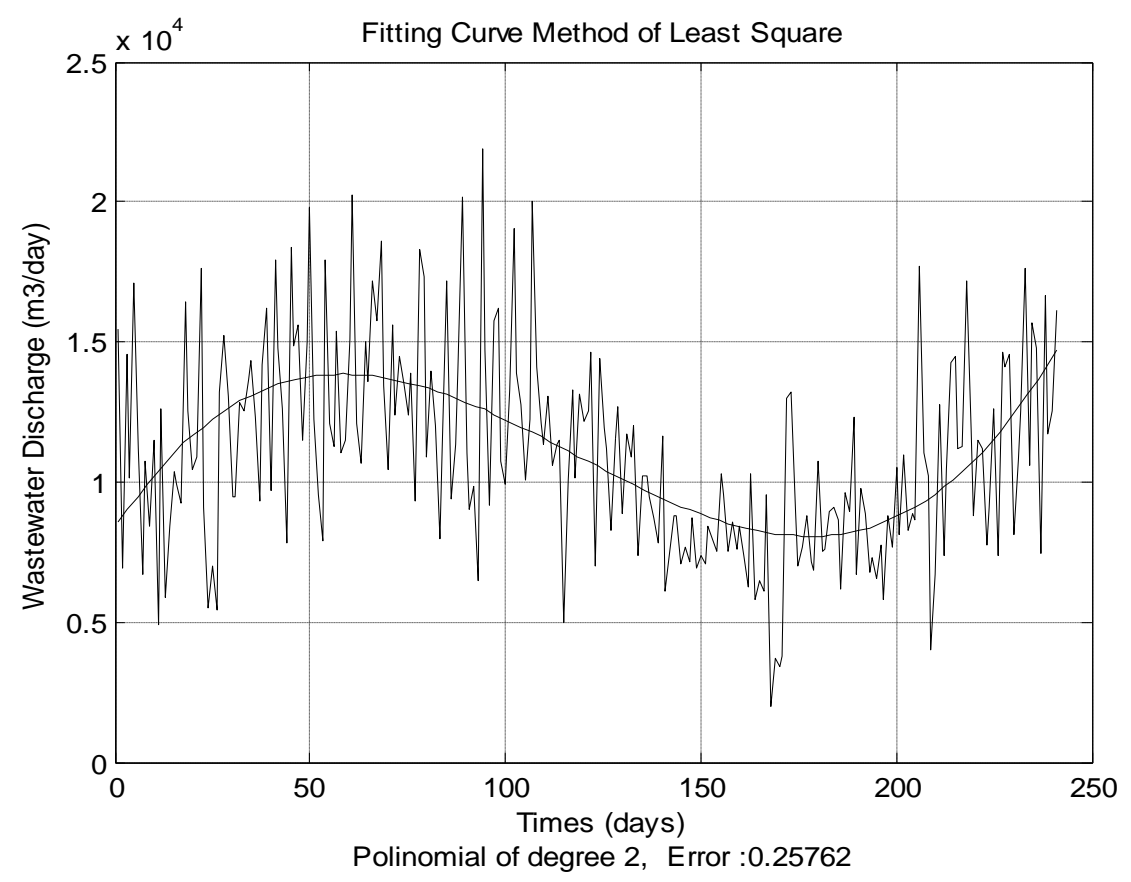

Figure 1. Daily Wastewater Discharge in Sewon WWTP

Figure 1 shows the wastewater discharge tendency pattern followed by trend method of least square pattern with the tendency of polinomial of degree 2 with magnitude error which shows the tendency of function whether it is linear or non-linear.

The wastewater discharge in Sewon WWTP varies from time to time. This condition is really needed related to the planning of WWTP in controlling wastewater quality in minimum water discharge, average discharge, peak discharge (Metcalf and Eddy, 1997). Wastewater average, minimum and maximum discharges in Sewon WWTP are shown in Figure 2.

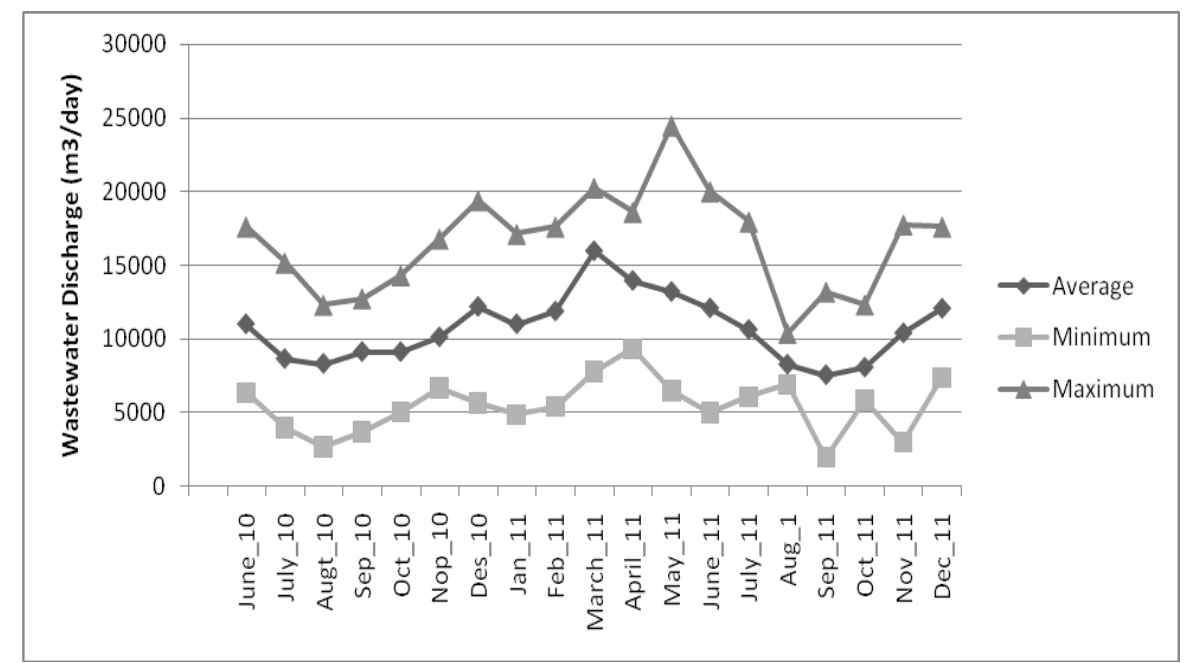

Figure 2. The Average, Minimum and Maximum Discharges of Wastewater in Sewon WWTP 


\section{Macrothink}

Figure 2 shows that the wastewater discharge in Sewon WWTP is fluctuative each month. It can be seen from the similar trend pattern among the minimum, maximum and average discharges of wastewater. The wastewater discharge in March and April was the highest one since these are in rainy season, while September 2011 had the lowest wastewater discharge as it was in dry season. This condition shows the magnitude of the discharge in equalization basin to overcome the operational problem. By having discharge variety, it can be handled to control wastewater quality in waste processing units.

Equalization is not a treatment process, but it is a way or technique to increase the next treatment process efectivity. The output from equalization basin becomes the operational parameter for the next processing units, such as flow, degrees, pollutant content temperature and solids. The function is to divide and level the supply volume (influent) to enter to the treatment process. The real daily average discharge condition of wastewater in Sewon WWTP is $10,697.53 \mathrm{~m}^{3} /$ day. Based on the wastewater quality planning standard in Sewon WWTP is:

- The quantity of input waste : $15,500 \mathrm{~m}^{3} /$ day (179 liter/second).

- The maximum quantity per hour : $1,282 \mathrm{~m}^{3} /$ hour (356 liter/second)

- $\quad$ BOD loads : 5,103 kg/day (46 gr/person/day)

- The input flow of BOD : $332 \mathrm{mg} / \mathrm{liter}$

- The output flow of BOD : $30-40 \mathrm{mg} / \mathrm{liter}$

Based on the planning, the input wastewater capacity is $15,500 \mathrm{~m}^{3} /$ day. It shows that based on the quality control data, the input wastewater in Sewon WWTP is $10,697.53 \mathrm{~m}^{3} /$ day. It means that it has not exceeded the planning capacity. However, in the application, Sewon WWTP is functioned to serve 23,000 housing lines, with the average capacity of $9,700 \mathrm{~m}^{3} /$ day in 2010 , for 11,000 housing lines. In 2011 , the used capacity became $10,697.53 \mathrm{~m}^{3} /$ day. There is an increase for $997.53 \mathrm{~m}^{3} /$ day $(10.28 \%)$.

\subsection{Wastewater Treatment in WWTP}

The treatment process in Sewon Bantul WWTP is a biological process using Facultative Aeration Lagoon (LAF) system. It relies on facultative ponds. Maturation process is intended to eliminate micro organism existed in maturation ponds. The treatment process is made into a parallel of 2 (two) rows. Each row contains 2 (two) facultative ponds and 1 (one) maturation pond. So, there are 4 (four) facultative ponds and 2 (two) maturation ponds. The ponds layout is presented in Figure 3. 


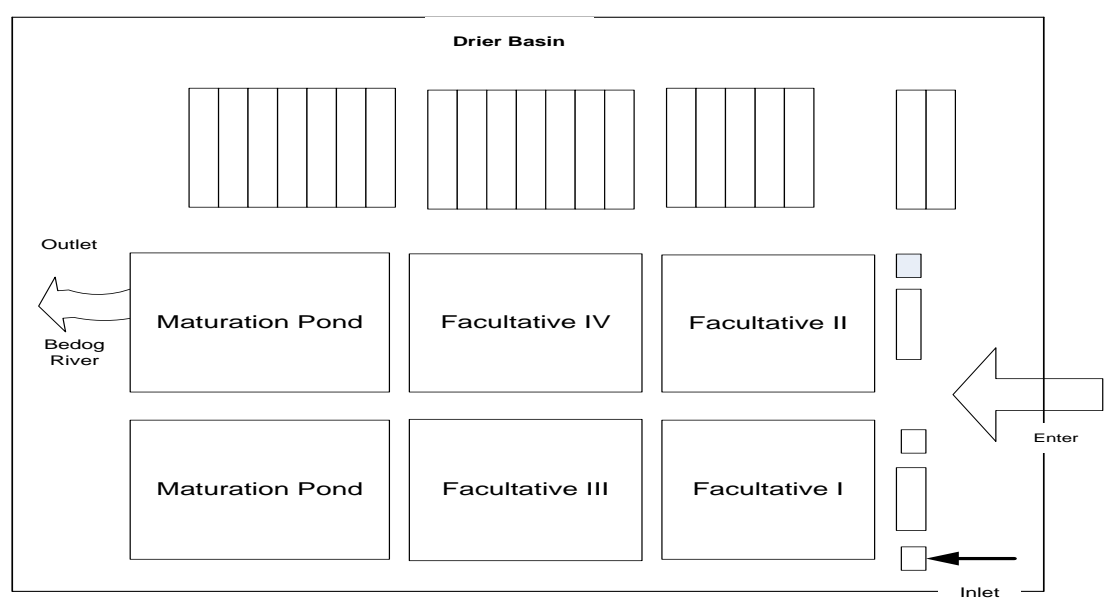

Figure 3. The layout of facultative ponds

The effective volume of facultative ponds is $86,240 \mathrm{~m}^{3}$ and the daily average discharge per month is different. It will influence reformation pace number of organic material $(k)$ for 0.94 day, retention time for 4.27 day and organic material decreasing efficiency of BOD for $72.33 \%$ (Sunarsih, 2011). Figure 4 and 5 show the level of concentrating alteration of daily organic material (BOD) as they enter and exit the ponds in Sewon WWTP. Figure 6 shows the number of BOD degradation rate (value $k$ ).

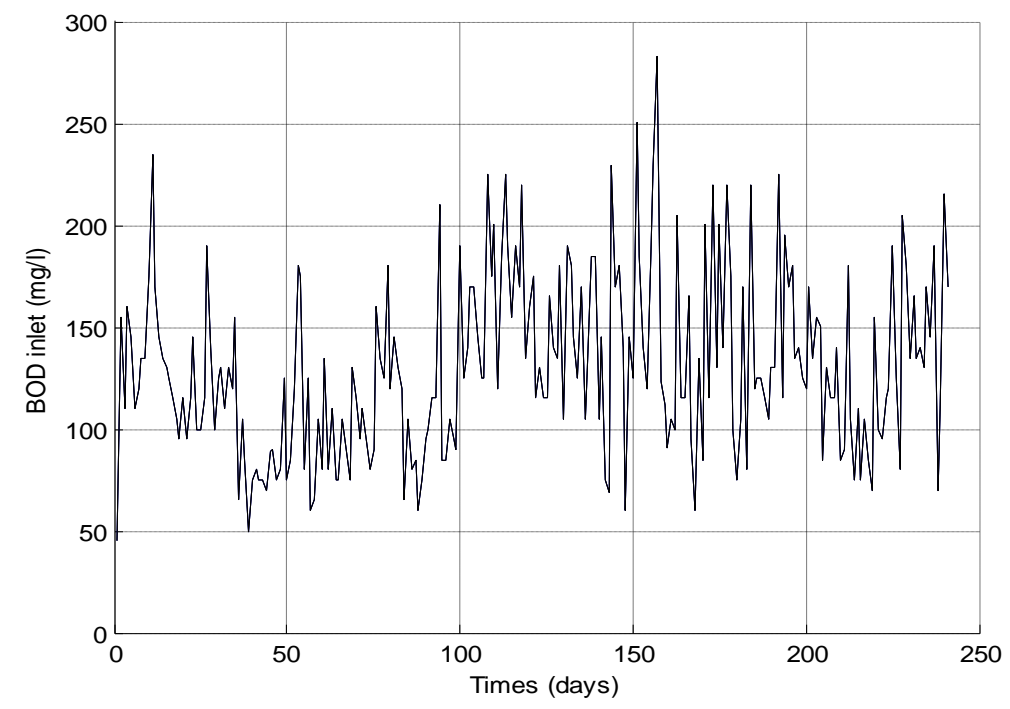

Figure 4. Concentration of daily BOD in Sewon WWTP Inlet. 


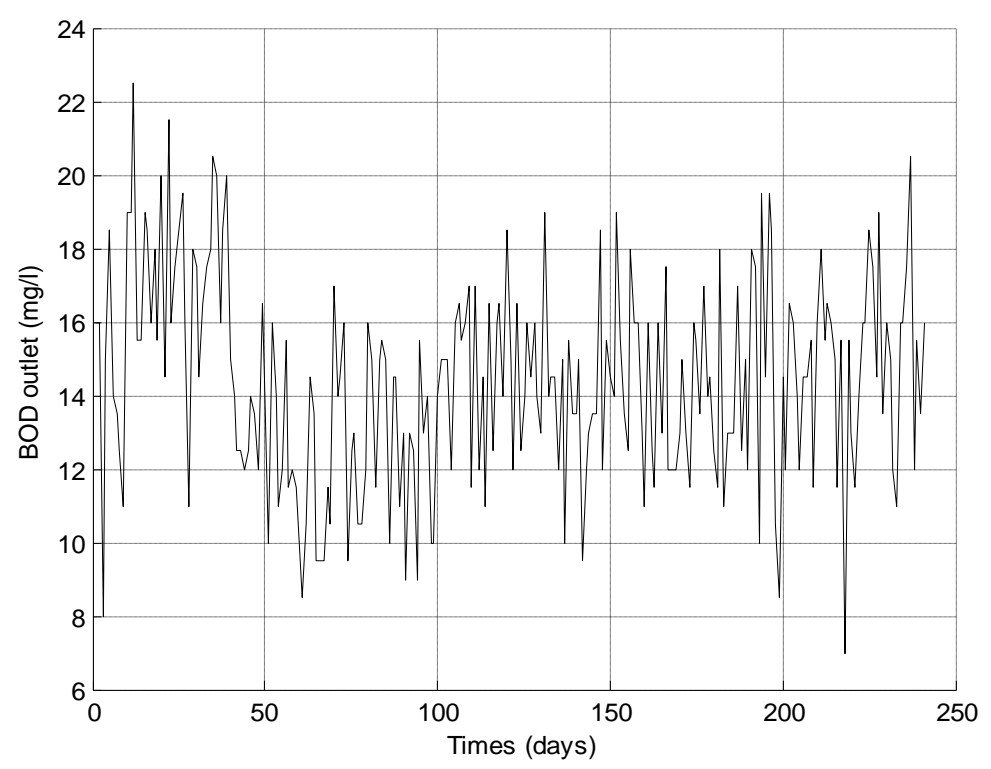

Figure 5. Concentration of daily BOD in Sewon WWTP Outlet

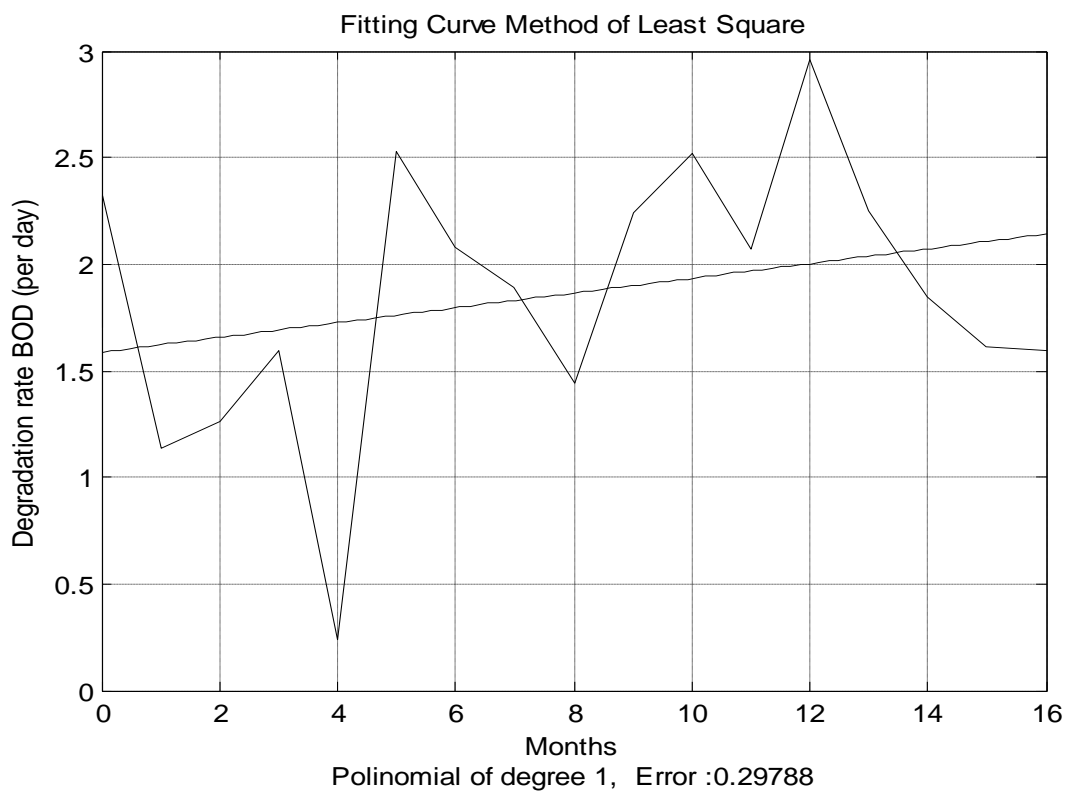

Figure 6. The number of BOD Degradation Rate $(k)$

The system of Facultative Aeration Lagoon (LAF) is applied in facultative ponds. In the maturation ponds, there are maturation processes to eliminate microorganism. The degradation rate of organic material $(k)$ is $1.85 \mathrm{day}^{-1}$ in the average and retention time of wastewater is 4.27 day. The value of criteria parameter for the degradation rate of organic material is $0.85-1.5$ day $^{-1}$ and wastewater processing time is $3-20$ days, with the processing efficiency of $90 \%$ (Gloyna, 1971) and the value of $k$ is 0.94 day $^{-1}$. It is still appropriate with the value of planning.

Thirumurthi (1974) and Mara (2003), using the value of $k$ between $0.1-2.0$ day $^{-1}$, show that WWTP is still good enough to degrade wastewater. Based on the research, the level of BOD 
decrease is $86.54 \%$, the dispersion factor is 0.25 and the value of $k$ is 1.85 day $^{-1}$ in the average. Based on the graph of Thrirumurthi (1974), the relation between the value of $k$ with the percentage of the remaining BOD make the value of $k$ becomes 2.7 day $^{-1}$. The planning criteria of decreasing efficiency of BOD value for $80 \%-90 \%$ is used to show that the function of wastewater managemen unit in WWTP Sewon is still efficient.

The ability of wastewater treatment unit in WWTP, presented by the value of organic material degradation pace $(k)$, varies each month. The result shows that every month, it has the varied value of degradation pace between $0.24-2.96$ day $^{-1}$ and 1.85 day $^{-1}$ in the average. It also shows the wastewater sediment time between $2.74-5.8$ day and 4.27 day in the average. This condition shows that the shorter the wastewater sediment time is, the bigger and faster the degradation pace value will be. It depends on wastewater which enters in the WWTP system. Regarding to the value of degradation pace of this wastewater treatment system, the treatment should be more aware of WWTP unit system. It happens as there are $13 \%$ of organic material loads which have not been used. In addition, the planning of wastewater quality standard in IPAL for service operational system is still $23 \%$. If the treatment intends to optimilize the existed network system, they should review the planning design of WWTP system.

The wastewater concentration total of BOD loads reaches $4,799.6 \mathrm{~kg} / \mathrm{day}$. It is resulted from the organic wastewater loads (BOD) that enter Sewon WWTP. It is linked to 119,990 people who generate $40 \mathrm{gr}$ of BOD per day per person. The concentration total is still under the planning loads of WWTP Sewon, that is $5,103 \mathrm{~kg} /$ day. The planning of organic wastewater loads (BOD) is intended for those who generate $46 \mathrm{gr}$ of BOD per day. It is obtained if BOD loads, calculated from loads planning standard of Sewon WWTP, is 5,519.59 kg/day. There are still unused loads of BOD for $416.54 \mathrm{~kg} /$ day $(8.16 \%)$ from the planning standard and wastewater loads from feces vacuum cars, whereas the ability of WWTP operational system is still 23\%. The technique requirements for sludge quality in WWTP is 0.5 liter/person/day and $\mathrm{BOD}_{5}$ is $5,000 \mathrm{mg} /$ liter. It has to fulfil the requirement of sludge capacity or pace (liquid and sediment). Thus, if IPAL treatment wants to increase the operational system of dirty water network, they need to review the planning standard of wastewater quality in WWTP to be more optimal and efficient.

\section{Conclusion}

Means of wastewater treatment in cities generate $40 \mathrm{gr}$ of BOD per day per person and the usage of clean water is 120 liter/person/day. The concentration total of BOD loads in WWTP Sewon is $4,799.6 \mathrm{~kg} /$ day for 119.990 people who connection to the sewer systems. The planning standard of WWTP for wastewater loads is $5,103 \mathrm{~kg} /$ day. If every person has loads of 46 gr of BOD per day, it will generate BOD loads for 5,519.59 kg/day. There are unused BOD loads for $416 \mathrm{~kg} /$ day $(8.16 \%)$ in the ability of WWTP operational system for $23 \%$. It does not include wastewater from feces vacuum cars for $5,000 \mathrm{mg} / \mathrm{l}$. It has the degradation rate for 1.85 day $^{-1}$ in average and the retention time for 4.27 day. It is also able to degrade organic matter for $86.54 \%$ in average. Thus, Sewon WWTP is still efficient as the wastewater treatment system.

If it is estimated from wastewater loads, which become generations of organic materials in 


\section{Macrothink}

Sewon WWTP, the system is suitable with the field current condition to reduce wastewater contamination in medium sized cities. The research also uses significant linear equation of $\mathrm{p}<$ 0.1 .

\section{Acknowledgement}

Thanks to the leaders and staff of Sewon WWTP, Public Works Department, Housing and ESDM Local Government Yogyakarta who have given permission for the research and data collection quality control of wastewater Sewon WWTP.

\section{References}

Beran, B., \& Kargi, K. (2005). A Dynamic Mathematical Model for Wastewater Stabilization Ponds. Ecological Modelling, 181, 39-57. http://dx.doi.org/10.1016/j.ecolmodel.2004.06.022

Campos, H. M., \& Von Sperling, M. (1996). Estmation of Domestic Wastewater Characteristics in a Developing Country Based on Socioeconomic Variables. Water Science and Technology, 34(3/4), 71-77. http://dx.doi.org/10.1016/0273-1223(96)00558-6

Gloyna, E. F. (1971). Waste Stabilization Pond. WHO, Genewa.

Hadi, S. P. dan Samekto, A. (2007). Dimensi Lingkungan Dalam Bisnis Tanggung Jawab Sosial Perusahaan pada Lingkungan.Badan Penerbit Universitas Diponegoro, Semarang.

Kayombo, S., Mbwette, T. S. A., Mayo, A. W., Katima, J. H. Y., \& Jorgensen, S. E. (2002). Diurnal Cycles of Variation Physical-Chemical Parameters in Waste Stabilization Ponds. Ecological Modelling, 18, 287-291.

Keputusan Menteri Negara Lingkungan Hidup No. 112 tahun 2003 tentang Baku mutu Air Limbah Domestik.

Ligman,K., Hutzler, N., \& Boyle, W. C. (1974). Household Wastewater Characterization. ASCE Journal of the Environmental Engineering Division. February, 1974, 201- 215.

Mahida, U. N. (1993). Pencemaran Air dan Pemanfaatan Limbah Industri. PT. Raja Grafindo Persada, Jakarta.

Mara, D. (1976). Sewage Treatment in Hot Climate. John Wiley and Sons, Toronto.

Mara, D. (2004). Domestic Wastewater Treatment ini Developing Countries. First Published by Earthscan in the UK and USA.

Martopo, S. (1987). Dampak Limbah Terhadap Lingkungan. Kursus Singkat Penyaringan Limbah Secara Hayati, Yogyakarta.

Mashauri, D. A., Kayombo, S. (2002). Application of the two coupled models for water quality treatment : facultative pond cum constructed wetland models. Physics and Chemistry of the Earth, 27, 773-781. http://dx.doi.org/10.1016/S1474-7065(02)00065-7

Peraturan Daerah No. 6 dan No. 7 Tahun 2009 tentang Retribusi.

Puspita, L, Ratnawati, E., \& Suryadiputra, I. N. N. (2005). Lahan Basah Buatan di Indonesia. 


\section{Macrothink \\ Environmental Management and Sustainable Development \\ ISSN 2164-7682 \\ 2013, Vol. 2, No. 2}

Wetlands International Indonesia Programme. Ditjen PHKA. Bogor.

Soemarwoto, O. (1993). Ekologi Lingkungan Hidup dan Pembangunan. Penerbit Jambatan, Jakarta.

Sunarsih, P., \& Wahyu, S. B. (2011). Interpolasi Newton untuk Karakteristik Biologi Kualitas Air Limbah Domestik pada Kolam Stabilisasi Fakultatif Instalasi Pengolahan Air Limbah Sewon Bantul. Prosiding Seminar "Penelitian Masalah Lingkungan di Indonesia" ISSN No. 2088 - 4818. pp 487-496.

Thirumurthi, D. (1974). Design Criteria for Waste Stabilization Ponds. Journal of the Water Pollution Control Federation, 46(9), 2094 - 2106.

\section{Glossary}

BOD : Biological Oxygen Demand

LAF : Facultative Aeration Lagoon

WWTP : Wastewater Treatment

UMP : Province Minimum Wage

\section{Copyright Disclaimer}

Copyright reserved by the author(s).

This article is an open-access article distributed under the terms and conditions of the Creative Commons Attribution license (http://creativecommons.org/licenses/by/3.0/). 